\section{W.E.UPJOHN INSTITUTE \\ FOR EMPLOYMENT RESEARCH}

\section{Employment Research Newsletter}

7-1-2009

\title{
Adding Labor Demand Incentives to Encourage Employment for the Disadvantaged
}

Timothy J. Bartik

W.E. Upjohn Institute for Employment Research, bartik@upjohn.org

Upjohn Author(s) ORCID Identifier:

(D) https://orcid.org/0000-0002-6238-8181

Follow this and additional works at: https://research.upjohn.org/empl_research

Part of the Labor Economics Commons

\section{Citation}

Bartik, Timothy J. 2009. "Adding Labor Demand Incentives to Encourage Employment for the Disadvantaged." Employment Research 16(3): 7. https://doi.org/10.17848/1075-8445.16(3)-6 
Timothy J. Bartik

\section{Adding Labor Demand Incentives to Encourage Employment for the Disadvantaged}

E ven after the U.S. economy recovers, there are likely to be considerable long-term employment problems for the disadvantaged. For example, even in 2006, when the U.S. economy was near a business cycle peak, employment rates for less-educated male workers were still well below where they were 30 years ago. To match lesseducated male employment rates from 1979, the United States in 2006 would have needed to add about 3 million jobs (Bartik and Houseman 2008). In addition, employment rates of less-educated unmarried women in 2006 were still well below those of men, even though under welfare reform these women are expected to work and be self-supporting.

In addition to finding ways of expanding job training programs and improving educational attainment, we need approaches to expanding labor demand for disadvantaged workers. Studies have shown that if disadvantaged workers can be hired for entry-level jobs and stay employed for at least six months, they gain valuable labor market experience, self-confidence, and a better reputation with employers, all of which increase their long-term employability and earnings.

In my 2001 book Jobs for the Poor: Can Labor Demand Policies Help? (Bartik 2001, chaps. 8 and 10) I suggest that the United States establish a permanent version of a program that Minnesota tried in the 1980s, the MEED program. MEED at first stood for Minnesota Emergency Employment Development, and later for Minnesota Employment and Economic Development.
Under my proposed national version of MEED, the federal government would provide wage subsidies of up to $\$ 8$ an hour for employers who hire unemployed workers referred by local workforce agencies for newly created positions. For several reasons, the program would be a discretionary program administered by local workforce agencies. First, this would allow the program to be integrated with local workforce programs. Second, a discretionary program could be selective in targeting employers who would be most willing to offer good job experiences to disadvantaged workers. Third, a discretionary program could target disadvantaged workers who would be good matches for interested employers, which would increase the effectiveness of the program.

The subsidies would go to newly created positions to minimize displacement. This program is intended to increase total employment rather than to substitute disadvantaged workers for other workers.

The wage subsidies would target small businesses and small nonprofit employers. The evidence suggests that these smaller employers may be the most responsive to a wage subsidy. Including both for-profit and nonprofit employers also allows the program to provide a wide variety of job experiences, and to provide both private and public services.

The wage subsidies would fund up to six months of labor market experience. Employers would be encouraged to roll over those hired into permanent job slots. Employers that abused the wage subsidy system would be excluded from future subsidies.

Evidence from the MEED program suggests that such a program can be successfully run on a large scale. Furthermore, studies find that about half of the jobs subsidized would not have been created but for MEED. The program was run in Minnesota on a scale that would be equivalent to having about 600,000 annual participants on a national level (Rode 1988).

A program run at a similar level nationally in the United States might cost about $\$ 8$ billion a year. This would include both the cost of the wage subsidy and the costs of various types of job training and social support for disadvantaged workers who are hired.

The long-term effects of this program should be regularly monitored through a performance-monitoring system. This system would track the postprogram employment and earnings history of program participants, compared to similar nonparticipants.

The research literature on wage subsidies suggests that such a program may have long-term effects. Perhaps 20 percent of the extra employment experience of program participants in the short run is likely to be reflected in increases in long-term employment rates of program participants. If run over a sustained period, this program has the potential to make a substantial dent in the depressed employment rates of disadvantaged groups.

\section{References}

Bartik, Timothy J. 2001. Jobs for the Poor: Can Labor Demand Policies Help? New York: Russell Sage Foundation; Kalamazoo, MI: W.E. Upjohn Institute.

Bartik, Timothy J., and Susan N. Houseman, eds. 2008. A Future of Good Jobs? America's Challenge in the Global Economy. Kalamazoo, MI: W.E. Upjohn Institute.

Rode, Peter. 1988. MEED Means More Business: Job Growth through Minnesota's Wage Subsidy Program. Minneapolis: Jobs Now Coalition.

Timothy J. Bartik is a senior economist at the Upjohn Institute. 